\title{
KONSEP TALAK DALAM KEADAAN MARAH DALAM PERSPEKTIF IBNU QOYYIM AL-JAUZI
}

\author{
MUHAMMAD NOOR \\ Politeknik Negeri Tanah Laut Pelaihari \\ muhammadnoorpolitala@gmail.com
}

\begin{abstract}
Abstrak
Dalam setiap literatur yang membahas masalah talak pasti akan kita dapatkan pernyataan bahwa ulama mazhab sepakat "diantara syarat-syarat talak adalah berakal sehat". Dari pernyataan ini akan menimbulkan pertanyaan bagaimana hukum talak dalam keadaan marah?

Marah merupakan sifat buruk, etika tercela, virus mematikan, keburukan yang pandemic, dan penyakit berbahaya. Oleh karena itu seorang muslim dituntut untuk menghancurkan angkara murka, dan menjauhinya. Apabila kemarahan melanda seseorang, maka dia wajib untuk meredakannya.

Dari hasil analisis penulis tentang permasalahan tersebut, maka hukum talak dalam keadaan marah menurut konsep Ibnu Qoyyim al-Jauzi terperinci sebagai berikut:

Pertama: Marah yang dapat menghilangkan akal. Orang yang berada dalam kondisi seperti ini tidak akan menyadari apa yang diucapkannya. Tidak diperselisihkan lagi bahwa talak orang yang marah seperti ini tidak sah.

Kedua: Mempunyai sifat marah yang tidak menghalangi pelakunya untuk mengutarakan apa yang diinginkan. Talak orang seperti ini sah.

Ketiga: Selalu berupaya untuk mengkondisikan marahnya hingga akalnya tidak hilang, tetapi masih memisahkan dirinya dengan niatnya. Kondisi ini masih diperdebatkan.
\end{abstract}

Kata Kunci: Talak dalam Keadaan Marah, Sifat Buruk.

\section{PENDAHULUAN}

(Thalib, 1997) Islam diturunkan Allah swt untuk umatnya ke dalam suatu tatanan yang bermoral. Islam tidak hanya mengatur hubungan Allah swt sebagai khalik dan manusia sebagai ciptaannya, tetapi juga turut mengatur hubungan antara manusia dngan manusia, termasuk juga dalam masalah hukum keluarga (al-ahwal alsyakhsiyah). Sebagai contoh, Islam mengatur hukum-hukum tentang perkawinan, mengenai hak-hak suami isteri dan etika berumah tangga.

(Mauludi, 1993) Tujuan utama hukum yang mengatur hubungan suami isteri adalah perlindungan dan pemeliharaan moral. Islam mencela perzinahan sebagai perbuatan yang melanggar hukum. Jika dorongan seksual kedua belah pihak disalurkan 
menurut kaidah hukum yang melindungi moral seseorang, maka berarti menghindarkan diri dari perbuatan tidak senonoh dan tidak sopan serta menjaga peradapan dari kehancurannay.

(Qardawi, 1996) Demikian pula setiap kekurangan dan kesengsaraan yang menghantam rumah tangga, mereka tanggung dan jalani bersama-sama pula, disinilah adanya ujian besar,sehingga keduanya harus dapat bersabar, saling memaafkan serta saling pengertian, jangan sampai suami isteri tidak bisa menahan dan membendung bujuk rayu syetan yang berakibat fatal bagi perkawinan mereka. Perkawinan yang seharusnya dilandasi dua format ilahiyyah: mawaddah dan rahmah, tapi justru ditunggangi dan dinakodai syetan.

(Hakim, 1934) Islam sebagai agama ilahy telah menggariskan aturan-aturan tentang firaq diantaranya adalah talak. Islam mengatur dan menetapkan bahwa talak adalah hak suami, sebab secara moril dan materil ia berkewajiban memberi nafkah kepada keluarganya.

(Sabiq, 2009) Cara firaq dengan talak, memang halal namun perbuatan tersebut dibenci allah swt, sebagaimana tercantum dalam hadis yang diterima dari sayyidina Umar bin khatab r.a,:

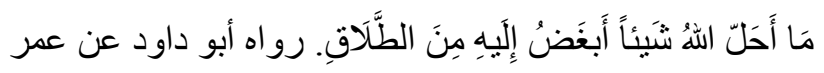

"Tidak ada sesuatu yang dihalalkan Allah lagi dibencinya tiada lain hanya talak"

Dan sebagaimana dalam hadis lain yang diterima dari Ibnu Umar, menyatakan :

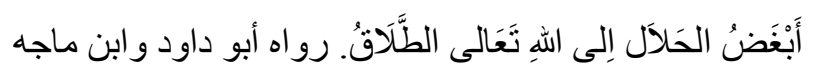

\section{"Perbuatan halal yang paling dibenci Allah adalah talak"}

Terdapat perbedaan pandangan ulama fiqih dalam menempatkan rukun talak. Ulama Mazhab Hanafi menyatakan bahwa rukun talak adalah lafal yang menunjukkan pengertian talak, yaitu ungkapan yang dapat melepaskan ikatan perkawinan dan menghentikan seluruh hubungan suami isteri. Adapun selain itu, menurut mereka, termasuk syarat.

Ulama Mazhab Maliki, Syafi'i, dan Hanbali menyatakan bahwa rukun talak itu ada empat, yaitu suami yang menjatuhkan talak, isteri yang ditalak, ada kehandak menjatuhkan talak, dan ungkapan yang digunakan dalam talak.

Diantara yang termasuk syarat yang tarkait dengan suami yang menalak. Ulama fiqih menyatakan bahwa suami yang menjatuhkan talak itu haruslah orang cakap bertindak hukum, yaitu balig dan berakal. Disamping itu, Ulama Mazhab Maliki 
menambahkan bahwa suami harus seorang muslim. Oleh karna itu, talak orang gila tidak jatuh atau sah karena mereka tidak cakap bertindak hukum. Hal ini selajan dengan sabda Rasulullah saw :

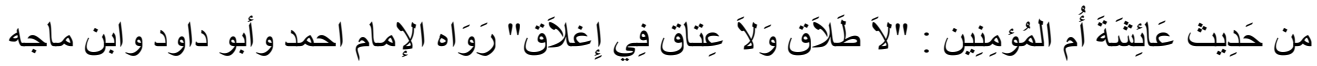

“Tidak sah talak dan pembebasan budak orang yang tertutup akalnya”(HR. Ahmad bin Hanbal, Abu Dawud, dan Ibnu Majah dari aisyah RA ). Dalam hadis lain dinyatakan :

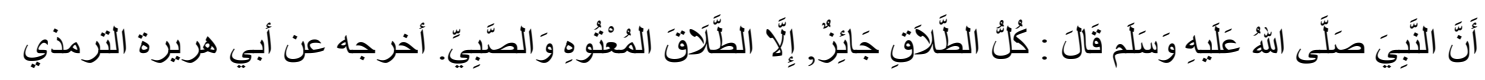

"Setiap talak itu boleh (jatuh), kecuali talak (yang dijatuhkan) anak kecil atau orang gila” ( HR. At-Tirmizi dari Abu Hurairah ).

Akan tetapi, Ulama Mazhab Hanbali menyatakan bahwa talak yang dijatuhkan anak kecil yang telah mumayiz adalah sah, berdasarkan keumuman hadis yang diriwayatkan oleh imam at-Tirmizi dari Abu Hurairah di atas.

(Praja, 1988) Ayat di atas jelas menyatakan bahwa perujukan segala sesuatu masalah harus dikembalikan kepada al-Qur'an dan as-Sunnah, akan tetapi mereka berbedapendapat dalam proses meng-istinbath dan merujuknya serta penerapannya sebab adanya perkembangan masyarakat, tempat, waktu dan lingkungan yang berbeda.

Terkait dengan pernyataan para ulama fiqih, bahwa talak dalam keadaan sangat marah tidak sah, apakah hal ini yang membuat Ibnu Qoyyim al-Jauzi berpendapat bahwa talak orang yang dalam keadaan marah tidak jatuh?

\section{TINJAUAN PUSTAKA}

Telah menjadi sebuah aksimo di dunia akedemis, bahwa tidak ada satupun bentuk karya seseorang yang teputus dari usaha intelektual yang dilakukan generasi sebelumnya, yang ada adalah kesinambungan pemikiran dan kemudian dilakukan perubahan yang signifikan. Penulisan Tesis ini juga merupakan mata rantai dari karyakarya ilmiah yang telah lahir sebelumnya, Khusus dalam pemikiran hukum Islam. Namun sejauh informasi yang penulis ketahui, penelaahan terhadap pemikiran Ibnu Qoyyim al-Jauzi yang secara khusus membahas tentang talak dalam keadaan marah, belum pernah penulis temui.

Hal tersebut tercermin dalam hasil karya baik hasil penelitian maupun buku yang relevan dengan permasalahan penelitian ini. Hasil penelitian yang membahas masalah talak, antara lain : 
Muhammad Noor (2009) mengulas tentang nikah dengan niat talak hukumnya boleh jika laki-laki berniat bahwa tatkala dia akan pergi, wanita tersebut mengagumkannya maka ia akan mempertahankannya sebagai isterinya, dan jika tidak maka ia akan menceraikannya. Adapun jika dia berniat menceraikannya secara pasti, maka hukumnya makruh.

Adliyansyah (2007 membahas tentang hukum kemelut rumah tangga yang yang berakhir dengan perceraian melalui surat dalam perspektif fikih Syafi'iyah, diantara yang termasuk rukun talak adalah shighat yang mempunyai kategori sharih dan kinayah, jumhur ulama baik kalangan mazhab empat maupun al-Zahiriy sepakat bahwa talak dengan shighat sharih adalah jatuh walaupun tanpa niat, sedangkan talak dalam kategori kinayah adalah jatuh bila dengan niat dan tidak jatuh bila tanta niat. Hal tersebut di atas sah bilamana langsung dan berada di hadapan isteri serta sesuai dengan syarat penjatuhan talak lainnya, akan tetapi ketika suami mengucapkan talak tersebut tidak selamanya secara langsung dan berhadapan dengan isteri, misalnya bila letak dan jarak mereka berjauhan, sedangkan kondisi menuntut agar (suami) menjatuhkan talak kepada isterinya. Oleh karna itu pihak suami bisa saja terdorong dalam dirinya untuk menuliskan kata-kata talaknya melalui sepucuk surat yang ia kirim kepada iaterinya karena suami mempunyai otoritas tentang talak. Dalam kondisi seperti di atas itu ulama berbeda pendapat Ibnu Hazm sebagai pengikut al-Zahiriy mengatakan bahwa talak yang dilakukan seperti tersebut di atas adalah tidak sah baik dibarengi niat ataupun tanpa niat, adapun Imam Malik maupun Abu Hanifah status hukum talak melalui surat (tulisan), apabila suami mentalaknya dan tidak melafalkannya serta tidak meniatkannya maka talaknya tidak jatuh. Sedangkan menurut Imam Ahmad talaknya jatuh.

Berbeda halnya dengan asy-Syafi'i beliau berkata apabila seseorang laki-laki tidak berada di hadapan isterinya (ghaib) lalu ia ingin mentalaknya dengan talak sunnah, maka ia menulis (kata-kata talaknya) kepada isterinya apabila tulisanku ini tiba kepadamu dan engkau telah haid setelah aku keluar darimu, maka bila telah suci engkau tertalak. Di lain kesempatan asy-Syafi'i menegaskan, apabila seseorang berisyarat yang bisa dipahami atau menulis (kata-kata talak) dalam suatu tulisan maka oleh karna itu lazimlah talaknya.

Islach (2008 menerangkan tentang nikah yang dilakukan dalam keadaan mabuk (hilang kesadaran) hukumnya tidak sah, karena melakukan satu tindakan hukum itu harus didasari akal yang sehat serta adanya maksud dan niat. Talak orang yang hilang kesadarannya karena kodrat yang kuasa (gila) hukum talak tersebut tidak sah menurut 
kesepakatan fukaha. Tetapi jika hilang kesadarannya sebab minum-minuman haram yang memabukkan karena terpaksa atau dipaksa, maka hukum talaknya menurut kesepakatan pakar fikih juga tidak sah, namun apabila minum-minuman yang memabukkan itu karena sengaja dan atas kemauman sendiri, hukum talaknya sah (jatuh) menurut jumhur (mayoritas) pakar fikih.

Demikianlah kajian pustaka yang dapat penulis paparkan, walaupun karya-karya ilmiyah di atas telah menjelaskan tentang hukum-hukum talak, namun pokok bahasan yang akan penulis kaji dalam artikel ini, berbeda dengan penulisan atau penelitian sebelumnya.

\section{METODE PENELITIAN}

\section{Jenis Penelitian}

Penelitian yang dilaksanakan ini berbentuk penelitian kepustakaan (Library research) yakni dengan menghimpun sejumlah literatur yang diperlukan untuk menyusun penelitian.

\section{Subjek dan Objek Penelitian}

Subjek penelitian ini adalah sejumlah literatur yang membahas langsung mengenai masalah pandangan Ibnu Qoyyim al-Jauzi tentang tidak jatuhnya talak dalam keadaan marah. Sedangkan yang menjadi objek dalam penelitian ini adalah pemikiran Ibnu Qoyyim al-Jauzi tentang status orang yang menjatuhkan talak istrinya dalam keadaan marah serta argumen-argumen beliau, serta latar belakang pemikiran Ibnu Qoyyim al-Jauzi tentang talak dalam keadaan marah.

\section{Sumber Data}

Adapun sumber data yang mendukung dalam penulisan ini dapat dibagi menjadi dua bagian, yaitu primer dan sekunder. Data primer terdiri dari : Ighostatu Lahfan fi Hukmi Talaqi Godban libni Qoyyim al-Jauzi, dan semua kitab-kitab Ibnu Qoyyim alJauzi khususnya dalam bidang fikih, Sedangkan data skunder adalah : Buku-buku fikih dan media cetak lain yang mendukung terhadap materi penulisan.

\section{Metode Analisis}

Dalam menganalisa data yang telah dihasilkan, penulis menggunakan analisis deskriptif dan kualitatif, yaitu jawaban atas rumusan masalah dengan kalimat yang 
ditata sedemikian rupa, hingga menjadi suatu bagian yang tidak terpisahkan dari penelitian ini.

\section{PEMBAHASAN}

Perkawinan merupakan alternatif satu-satunya dalam menghindari suatu perbuatan yang sangat dimurkai Allah swt. Era informasi global dan majunya tegnologi serta pengaruh budaya, akan berimbas pada merosotnya nilai-nilai moral masyarakat dan jauhnya dari ajaran agama. Walaupun era informasi global dan majunya tegnologi serta pengaruh budaya memberikan manfaatyang banyak dan dampak positif namun ada juga negatifnya terhadap kita jika kita tidak dibekali oleh iman. Islam yang merupakan filter bagi kita dalam rangka menyaring derasnya arus budaya dan informasi yang semakin menggelobal. Salah satu contoh adalah banyaknya pertengkaran rumah tangga yang berhujung kepada perceraian, yang tidak lain dikarenakan marahnya suami kepada isteri yang tidak terkontrol.

Secara umum, marah itu tercela. Ia merupakan sifat buruk, etika tercela, virus mematikan, keburukan yang pandemik, dan penyakit berbahaya. Betapa tidak, marah merupakan dorongan setan, dan setan diciptakan dari api neraka.

Oleh karena itu, sesungguhnya marah merupakan nyala api yang berasal dari api neraka. Api sendiri mempunyai karakter menyambar tak tentu arah, bergerak liar, bergelombang, menyala-nyala, dan meledak-ledak. Barangsiapa yang terbakar api kemarahan, maka kedekatannya dengan setan semakin mengikat. Karena kemarahan merupakan kunci segala keburukan, bahkan ia adalah kumpulan dari segala macam keburukan.

Jika demikian, maka melepaskan diri dari kemarahan merupakan himpunan dari seluruh kebaikan. Bahkan bersabar untuk tidak marah lebih berat dan susah dari berjuang melewati musuh sekalipun.

Tidak ada rumah tangga yang tidak sepi dari perselisihan dan pertikaian. Pun demikian dengan rumah tangga orang-orang saleh dan bertakwa. Orang-orang saleh dan bertakwa kadang terlibat perselisihan, pertikaian, konflik dan kemarahan. Akan tetapi, mereka cepat meredakan konflik dan amarah, serta kembali menenangkan diri.

(Sabiq, 2009) Dari analisa diatas bahwa, marah bisa mengakibatkan rusaknya hubungan rumah tangga yang dibangun di atas rasa ketulusan jiwa, dan kesadaran yang 
tinggi.Yang mana marah tersebut tidak dibenarkan oleh syariat Islam. Karena tujuan nikah tersebut untuk membangun bahtera rumah tangga yang sebenarnya.

Pengertian talak dalam keadaan marah adalah Talak yang dijatuhkan oleh suami yang sedang marah. Maksud dari orang yang marah adalah orang yang tidak menyadari perkataan yang telah dia katakan, dan tidak mengetahui apa yang dia lakukan. Dalam keadaan seperti itu, talak yang dijatuhkan tidak sah karena dilakukan tanpa keinginan orang yang menjatuhkan talak.

(Dahlan, 1996) Talak yang dijatuhkan oleh suami yang sedang marah. Menurut kesepakatan para ahli fikih, talak orang yang dalam keadaan sangat marah tidak sah berdasarkan hadis:

$$
\text { لَا طَكَلَق وَلَا عِنَاقَ فَي إِغْلَقِ. }
$$

"Tidak sah talak orang yang tertutup akalnya" (HR. Ahmad bin Hanbal, Abu Dawud, dan Ibnu Majah dari aisyah r.a).

Maksud dari orang yang marah adalah orang yang tidak menyadari perkataan yang telah dia katakan, dan tidak mengetahui apa yang dia lakukan. Dalam keadaan seperti itu, talak yang dijatuhkan tidak sah karena dilakukan tanpa keinginan orang yang menjatuhkan talak.

Dalam hal ini, kata iglaq ( إغْلَاقٍِ ) boleh diartikan dengan marah, dipaksa, dan gila. Ibnu Taimiyyah berkata di dalam kitab Zadu al-Ma'ad, bahwa arti sebenarnya dari kata iglaq ( إغْلَاقِ ) adalah tertutupnya hati seseorang, sehingga dia tidak sadar dan tidak mengerti akan apa yang dia katakan (seakan-akan seluruh tujuan dan keinginannya tertutup). Kata iglaq ( إغْلَاقِ ) juga mencakup makna talak yang dijatuhkan oleh orang (suami) yang dipaksa, orang yang tidak berakal (gila), orang yang hilang kesadaran karena mabuk atau marah, serta semua orang yang tidak memiliki maksud, dan tidak mengerti akan apa yang ia katakan.

(Sabiq, 2009) Menurut Ibnu Taimiyyah, marah ada tiga macam: Pertama: Marah yang bisa menghilangkan kesadaran sehingga orang yang marah tidak menyadari apa yang dia katakan. Karena itu, tanpa diperselisihkan, pada kondisi seperti itu hukum talak tidak sah. Kedua: Kemarahan ringan yang tidak mencegah seseorang (dalam hal ini adalah suami) untuk memahami maksud perkataannya. Pada kondisi seperti ini, apabila dia menjatuhkan talak, maka talaknya sah. Ketiga: Marah yang semakin bergejolak. Tetapi, tidak sampai menghilangkan kesadaran secara keseluruhan. Hanya saja, marah seperti ini menjadi penghalang antara orang yang marah dan niatnya, sehingga apabila marahnya hilang, dia akan menyesali apa yang telah terjadi ketika dia 
marah. Dalam kondisi seperti ini, ulama berbeda pendapat apakah talaknya sah atau tidak. Tetapi, pendapat yang paling kuat adalah pendapat yang menyatakan bahwa talaknya tidak sah.

(al-Jauzi, 1999) Ibnu Qoyyim al-Jauzi berpendapat bahwa, mengenai talak dalam keadaan marah, Imam Ahmad telah berkata dalam riwayat Hambali; hadis Aisyah ra, "Saya pernah mendengar Rasulullah saw Bersabda:

لَا طَلاَقَ وَلَا عِنَاقَ فَي إِغْلَقِ.

"Tidak sah talak orang yang tertutup akalnya" (HR. Ahmad bin Hanbal, Abu Dawud, dan Ibnu Majah dari aisyah r.a).

Ini adalah nash Imam Ahmad yang diceritakan oleh al-Khallal dan Abu Bakar dalam asy-Syafi dan Zad al-Musafir. Dalam sunan-nya, Abu Dawud mengatakan, "Saya menduga arti kata ighlaq adalah marah." Oleh karena itu, dia menuliskan judul bab alThalaq ala Ghalath (bab talak dengan kekeliruan).

Abu Ubaid dan yang lainnya menafsirkan kata tersebut dengan paksaan. Sementara ulama lainnya menafsirkannya dengan gila. Ada juga yang berpendapat bahwa itu merupakan larangan untuk menjatuhkan talak tiga sekaligus, sehingga tidak tersisa sedikitpun darinya.

Imam Ibnu Qoyyim al-Jauzi berkata, "Hakekat ighlaq adalah hati seseorang akan menjadi tertutup hingga dia tidak bermaksud untuk mengucapkan kata atau tidak memahaminya dengan baik. Sepertinya maksud dan keinginannya tertutup."

Abu al-Abbas al-Mubarrad berkata,"Al-ghalaqadalah sempitnya dada dan hilangnya rasa sabar hingga dia tidak mendapatkan penolong."

Imam Ibnu Qoyyim al-Jauzi menuturkan,’Talak orang yang dipaksa, orang gila, orang yang hilang akal karena mabuk atau marah termasuk dalam arti kata ini (alghalaq)."

Marah terbagi menjadi tiga macam: Pertama: Marah yang dapat menghilangkan akal. Orang yang berada dalam kondisi seperti ini tidak akan menyadari apa yang diucapkannya. Tidak diperselisihkan lagi bahwa talak orang yang marah seperti ini tidak sah. Kedua: Mempunyai sifat marah yang tidak menghalangi pelakunya untuk mengutarakan apa yang diinginkan. Talak orang seperti ini sah. Ketiga: Selalu berupaya untuk mengkondisikan marahnya hingga akalnya tidak hilang, tetapi masih memisahkan dirinya dengan niatnya. Kondisi ini masih diperdebatkan.

(Dahlan, 1996) Talak orang yang dalam keadaan sangat marah. Menurut kesepakatan para ahli fiqih, talak orang yang dalam keadaan sangat marah tidak sah 
berdasarkan hadis yang diriwayatkan oleh Imam Ahmad bin Hanbal, Imam Abu Dawud, dan Imam Ibnu Majah dari Aisyah binti Abu Bakar RA di atas. Akan tetapi, apabila dalam keadaan marah laki-laki tersebut masih mengetahui dan menyadari segala ucapan yang dikeluarkannya, maka talaknya sah kerena ia dianggap sebagai orang yang sadar.

\section{KESIMPULAN}

Menurut kesepakatan para ahli fiqih, talak orang yang dalam keadaan sangat marah tidak sah berdasarkan hadis yang diriwayatkan oleh Imam Ahmad bin Hanbal, Imam Abu Dawud, dan Imam Ibnu Majah dari Aisyah binti Abu Bakar RA di atas. Akan tetapi, apabila dalam keadaan marah laki-laki tersebut masih mengetahui dan menyadari segala ucapan yang dikeluarkannya, maka talaknya sah kerena ia dianggap sebagai orang yang sadar.

Imam Ibnu Qoyyim al-Jauzi berkata, "Hakekat ighlaq adalah hati seseorang akan menjadi tertutup hingga dia tidak bermaksud untuk mengucapkan kata atau tidak memahaminya dengan baik. Sepertinya maksud dan keinginannya tertutup.”

Imam Ibnu Qoyyim al-Jauzi menuturkan,’Talak orang yang dipaksa, orang gila, orang yang hilang akal karena mabuk atau marah termasuk dalam arti kata ini (alghalaq).”

\section{DAFTAR PUSTAKA}

Abu A'ala Mauludi, (1993), Kawin dan Cara Menurut Islam, diterjemahkan oleh Achmad Rais, cet. 4, Gema insani Press, Jakarta.

Abdul Azis Dahlan, (1996), Ensiklopedi Hukum Islam, cet. 1 jil.5, Ichtiar Baru Van Hoeve, Jakarta.

A.Mudjib Mahalli, (2001), Menikahlah Engkau Menjadi Kaya, cet. 1 Mitra Pustaka, Yogyakarta.

Ibnu Qoyyim al-Jauzi, (1999), Zadul Ma'ad, Cet, 1, Dar At-Taqwa lil Nasyr wa AtTauzi, Jakarta.

al Manar al Munif fi al Shahih wal Dhaif,(judul terjemahan : Studi Kritik terhadap Hadits fadhilah Amal)

Depertamen Agama RI, (1971), Al-Qur'an dan Terjemahnya, Yayasan Penyelenggara Penterjemah/Penafsir Al-Qur'an, Jakarta. 
Drs. Bimo Walgito, (1984), Bimbingan dan Konseling Perkawinan, Yayasan Penerbitan Fakultas Psikologi Universitas Gajah Mada, Yogyakarta.

http://anshorulloh.wordpress.com/10-06-2011

http://abuamincepu.wordpress.com/Atau http://anshorulloh.wordpress.com/10-06-2011

Imam Suprayogo dan Tabrani, (2001) Metodologi Penelitian Sosial Agama, PT Remaja Rosdakarya Bandung.

Memed Humeaedillah, (2002), Status Hukum Akad Nikah Wanita Hamil dan Anaknya, Gema Insani Press, Jakarta.

Muhammad al-Afifi, (2011), Fikih Marah, Group Cicero Publishing, Jakarta.

M.Thalib, (1997), 15 Perceraian dan Penanggulangannya. cet ke 10, Irsyad Baitus Salam, Bandung.

M. Thahir Makmun, Lc. cet. 1, Pena Pundi Aksara, Jakarta.

M.Yusuf Qardawi, (1996), Bagaimana Memahami Syari'at Islam, Terjemah Nabhani Idris, Islamuna Press, Jakarta.

M.Khaled Muslih dan H.Imam Awaluddin, (2006), Biografi 10 Imam Besar, cet, 2, Pustaka Al-Kautsar, Jakarta.

Pius A Partanto dan M. Dahlan Al-Barry, (2001), Kamus Ilmiah Populer, Arkola, Surabaya.

Sayyid Sabiq, (2009), Fiqhu Sunnah, diterjemahkan oleh M.Ali Nursyidi, Lc. dan Hunainah

Wahab Khalaf, (1978), usul fikih. 